Discussion Paper No. 17-008

\title{
Country-by-Country Reporting:
}

Tension between

\section{Transparency and Tax Planning}

Maria Theresia Evers, Ina Meier, and Christoph Spengel

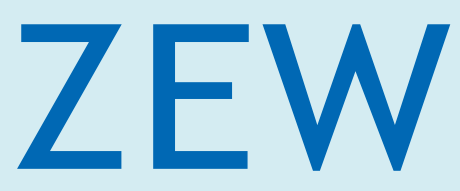

Zentrum für Europäische Wirtschaftsforschung $\mathrm{GmbH}$

Centre for European Economic Research 
Discussion Paper No. 17-008

\title{
Country-by-Country Reporting: Tension between Transparency and Tax Planning
}

\author{
Maria Theresia Evers, Ina Meier, \\ and Christoph Spengel
}

Download this ZEW Discussion Paper from our ftp server:

http://ftp.zew.de/pub/zew-docs/dp/dp17008.pdf

Die Discussion Papers dienen einer möglichst schnellen Verbreitung von neueren Forschungsarbeiten des ZEW. Die Beiträge liegen in alleiniger Verantwortung der Autoren und stellen nicht notwendigerweise die Meinung des ZEW dar.

Discussion Papers are intended to make results of ZEW research promptly available to other economists in order to encourage discussion and suggestions for revisions. The authors are solely responsible for the contents which do not necessarily represent the opinion of the ZEW. 


\title{
Country-by-Country Reporting:
}

\section{Tension between Transparency and Tax Planning}

\author{
Maria Theresia Evers*, Ina Meier**, Christoph Spengel***
}

November 2016

\begin{abstract}
Aggressive tax planning efforts of highly profitable multinational companies (Base Erosion and Profit Shifting (BEPS)) have become the subject of intense public debate in recent years. As a response, several international initiatives and parties have called for more transparency in financial reporting, especially by means of a Country-by-Country Reporting (CbCR). In line with that, the OECD and the European Commission have recently presented proposals for a comprehensive disclosure of country-specific tax-related information for companies in all industry sectors. In our paper, we demonstrate that neither consolidated or individual financial statements nor other existing data sources seem to be an appropriate basis for providing such country-specific information. Instead, it would be necessary to define detailed and harmonized definitions and regulations to ensure comparability. The discussion on benefits and costs of a CbCR reveals that benefits (at least partially) lack a theoretical foundation and, overall, do not seem to outweigh associated costs. This holds true, in particular, since current tax planning activities are mainly based on the legal exploitation of gaps and loopholes in national and international tax law. Instead, we argue that tax legislators should limit profit shifting by enforcing tax rules and by closing gaps in tax law. In particular, we call for more tightened and standardized transfer pricing regulations and thin-cap rules to be adopted at an international level.
\end{abstract}

JEL Classification: H20, H26, F23, K34, M41

Keywords: tax avoidance; profit shifting; multinational firms; tax reform; tax reporting; country-by-country reporting; international transfer pricing

\footnotetext{
* ZEW

** $\quad$ University of Mannheim

*** University of Mannheim \& ZEW Mannheim
}

This essay is based on the paper by Evers et al. (2014). It has been awarded by the "Stiftung Wissenschaftsform Wirtschaftsprüfung und Recht” with the "Stiftungspreis 2016”. 


\section{Introduction}

Tax planning efforts of highly profitable US multinationals such as Google, Apple or Amazon and their extremely low effective tax rates on their non-US profits have become the subject of intense public debate over the last years. ${ }^{1}$ The fact that these companies pay almost no corporate taxes in the foreign jurisdictions they operate in can most likely be attributed to activities aimed at shifting profits to tax havens. To this end, companies effectively exploit gaps and loopholes in international tax laws, such that their endeavors do not in general classify as illegal. Yet, the acceptability of such activities from a social and ethical point of view is widely discussed; some call it 'aggressive' even though a clear distinction between 'acceptable’ and 'aggressive' tax planning is hard to define.

Although there have been several attempts to quantify the scale of profit shifting, ${ }^{2}$ no accurate estimate of the exact amount of profits transferred to low tax jurisdictions exists to date. There is, however, reason to believe that the problem has been considerably overestimated. ${ }^{3}$ Nevertheless, empirical evidence clearly shows that profit shifting within multinationals does indeed take place regardless of the specific industry sector. In that respect, several channels have been identified: On the one hand, international tax rate differentials are found to be the major driver of profit shifting (Grubert and Mutti (1991); Hines and Rice (1994); Huizinga and Laeven (2008); Egger et al. (2010); Dharmapala and Riedel (2013); Fuest et al. (2011); Heckemeyer and Overesch (2013)). On the other hand, debt financing as well as transfer pricing in general and licensing of Intellectual Property (IP) in particular are identified as the most important channels to relocate profits (Desai et al. (2004); Buettner at al. (2012); Clausing (2003); Desai et al. (2006); Dischinger and Riedel (2011); Karkinsky and Riedel (2012); Lohse and Riedel (2013); Dharmapala (2014)). Here, transfer pricing rather than debt financing turns out to be the dominant channel for profit shifting (Heckemeyer and Overesch (2013), p. 30).

As a countermeasure to this issue, the OECD released a global action plan against Base Erosion and Profit Shifting (BEPS) in July 2013 (OECD (2013a)). This action plan was adopted by the G-20 leaders ${ }^{4}$ and is - in principle - supported by the European Commission

For a detailed discussion see Fuest et al. (2013).

2 Murphy assumes that tax evasion and tax avoidance costs the EU member states 1 Trillion $€$ a year, see Murphy (2012), p. 2; according to Bach, in Germany the yearly revenue loss due to profit shifting amounts to ca. 90 Billion $€$, see Bach (2013), p. 3ff.; Heckemeyer and Spengel, however, assume the revenue loss in Germany to be less than 10 Billion $€$ and therefore much lower, see Heckemeyer and Spengel (2008), p. 54; Oxfam calculates a revenue loss of \$ 50 Billion for developing countries, see Oxfam (2000).

3 The OECD estimates a global revenue loss of only USD 100-240 Billion at 2014 levels, see OECD (2015d).

4 See http://en.g20russia.ru/news/20131129/784497471.html. 
(European Commission (2013), p. 4). Arguing that a lack of transparency in financial reporting facilitates profit shifting (Murphy (2009), p. 4), the OECD action plan also includes - among other things - specific actions (Action 11-13) aimed at enhancing the disclosure quality of tax-related information. More precisely, the OECD and the European Commission have recently released several proposals for a so-called Country-by-Country Reporting (CbCR). This concept is based on the disclosure of key business information such as profits and taxes paid for each country that a multinational operates in. The proponents of CbCR claim that the disclosure of such information might serve the purpose of detecting abusive tax arrangements. Furthermore, it is argued that this kind of disclosure could build up pressure on companies to pay a fair amount of tax in relation to their economic activity in each country. In this paper, we examine whether CbCR actually is an appropriate means to achieve these objectives or whether there are other measures to more effectively combat international profit shifting.

Our paper is organized as follows: First, we provide an overview of existing provisions and recent developments regarding CbCR (Section 2). Second, we discuss the current proposals of the OECD and the European Commission for a comprehensive CbCR and examine what data source for providing tax disclosure may be most appropriate. In addition, we analyze expected costs and benefits linked to country-specific reporting (Section 3). Third, we derive potential alternatives for reform (Section 4). Finally, we conclude (Section 5).

\section{Existing provisions and recent developments for Country-by-Country Reporting}

Until recently, there has not been any binding legislation prescribing a comprehensive CbCR for all countries and industry sectors. However, certain regulations requiring country-specific information have already been put in place, albeit only for specific sectors, namely the extractive (production of oil, natural gas and minerals) and financial sectors respectively. These specific CbCR-requirements are mainly outside the scope of financial reporting. The most comprehensive rulings concern the extractive industry, not because of tax reasons, but rather due to a high risk of corruption in this sector. The Extractive Industries Transparency Initiative (EITI), ${ }^{5}$ for instance, an international standard which countries may sign up to voluntarily, is basically aimed at reconciling company and government payments. Participating countries have the duty to produce a public report, but are, however, entitled to decide on the exact form and scope of disclosure. In contrast, according to the Dodd-Frank Act, listed companies in the US operating in the extractive sector are obliged to publish

\footnotetext{
5 http://eiti.org.
} 
payments made to governments on a country-by-country basis and in a standardized way. ${ }^{6}$ Similarly, the EU Accounting and Transparency Directive implemented in July 2013 requires EU (listed and large non-listed) companies in the extractive and forestry sectors to disclose payments to national governments as part of their annual financial statements. ${ }^{7}$ Yet, like the other two initiatives, it does not intend the declaration of country-specific profit figures and tax payments. By contrast, the EU Capital Requirements Directive IV ("CRD IV”) ${ }^{8}$, adopted in July 2013, is the first initiative governing country-by-country disclosure for financial institutions in the EU. Primarily aimed at the enhancement of transparency, this directive stipulates that all concerned companies publicly disclose the names of their operations, turnover and the number of employees in every relevant country, effective from 2014. Most important, however, are country-specific data on profits/losses and tax payments, which still have to be confidentially reported to the Commission only.

Recently, there has been a development towards enhanced transparency through stricter and more extensive disclosure requirements for companies in all industry sectors, which was mainly triggered by the publication of the OECD action plan on BEPS (OECD (2013a)). In particular, actions 11 to 13 of the plan address the collection of firm-level data on BEPS and the disclosure of aggressive tax planning arrangements that companies may make use of. Moreover, the action plan calls for the disclosure of country-specific tax-related information as a part of the transfer pricing documentation (OECD (2013b)). Taxpayers would be obliged to report income, taxes paid and certain indicators of economic activity to governmental authorities, i.e. CbCR information would not be made publicly available. While the Discussion Draft on Transfer Pricing Documentation and CbCR (OECD (2014a)) specified this concern by stipulating that CbCR should become a compulsory part of a master file of the transfer pricing documentation, the subsequent Guidance on Transfer Pricing Documentation and CbCR (OECD (2014b)) implemented a three-tiered structure where CbCR constitutes a separate part (besides a master and a local file). Later on, the OECD released the Guidance on the Implementation of Transfer Pricing Documentation and CbCR (OECD (2015a)) containing more details with regard to the scope of application (e.g. affected companies and time period) as well as the CbCR Implementation Package (OECD (2015b)) providing precise suggestions for implementation into national legislation. Eventually, the Final Report on

\footnotetext{
See Congress of the United States of America (2010). Similar regulations apply for companies listed at the Hong Kong Stock Exchange (HKEX).

7 Directive 2013/34/EC.

8 Directive 2013/36/EU.
} 
Transfer Pricing and CbCR (OECD (2015c)) summarized the OECD's proposals. ${ }^{9}$ These proposals should be implemented into national laws applying to fiscal years from 2016 onwards. Several countries have already realized such CbCR regulations in their national laws ${ }^{10}$ or have put forward specific draft proposals. ${ }^{11}$ As an additional step towards the implementation of a successful comprehensive CbCR, 82 countries have lately signed a multilateral competent authority agreement (MCAA) ${ }^{12}$ which serves as a base for the exchange of CbCR information among tax authorities. ${ }^{13}$

Likewise, the European Commission has put forward several proposals to promote a comprehensive CbCR. First, CbCR was launched as a major element of the Anti-Tax Avoidance Package (European Commission (2016a)) in January 2016. This initiative primarily resulted from the OECD's final CbCR proposal and is to a great extent in line with the suggested regulations. Furthermore, there has been introduced a draft that obliges national tax authorities to automatically exchange confidential CbCR information (European Commission (2016b)). ${ }^{14}$ This directive, stipulating a comprehensive CbCR for large EU multinationals, was adopted in May 2016 and should be implemented into national laws until 4 June 2017 (European Commission (2016c)). In addition to that, the EU released a CbCR Directive (European Commission (2016d)) as amendment to the existing Accounting Directive in April 2016 which envisages all large multinational companies operating in the EU to publicly disclose a limited CbCR entailing several tax-related information. Hence, Multinational Enterprises (MNE) operating in the EU would be under duty to file two separate reports: One full CbCR only available to tax authorities as well as one partial CbCR available to the public.

\section{Comprehensive Country-by-Country Reporting}

\subsection{Details of the current proposals}

The current OECD proposal provides quite extensive guidelines for a comprehensive CbCR concerning all industry sectors. ${ }^{15}$ They are intended to apply in the participating countries for fiscal years starting on January $1^{\text {st }} 2016$, but the report could be handed in one year later (by

9 For details on the specific content, please see section 3.

10 These countries include e.g. Spain, Poland, Denmark, France, the Netherlands, Italy, UK, Australia and Mexico.

11 E.g. Ireland, Norway, Belgium, USA, Germany.

12 See https://www.oecd.org/tax/automatic-exchange/international-framework-for-the-crs/.

13 Status: 12 May 2016. The US, for example, has instead opted for bilateral agreements.

14 The Draft Directive on the exchange of tax-related information was an amendment to the Administrative Cooperation Directive.

15 The current EU proposal is based on these guidelines as well. 
the end of 2017). The rulings shall be effective on a mandatory base ${ }^{16}$ for all large multinational corporations having annual consolidated group revenue of more than 750 Mio. Euro in the preceding fiscal year. It is expected that $90 \%$ of all multinational groups would therefore be exempted from the CbCR obligations, however, at the same time, CbCR would still be filed by groups controlling 90\% of corporate revenue (OECD (2015a), p. 4).

The OECD generally suggests CbCR to be part of the transfer pricing documentation. More precisely, they envisage a three-tiered approach consisting of a master file intended to provide transfer pricing information regarding all involved jurisdictions, a local file with countryspecific transfer pricing information which is only made available to the respective jurisdiction as well as the actual CbCR. The OECD claims that such a CbCR would serve tax authorities in assessing the transfer pricing risk as well as in detecting profit shifting activities. As far as the structure of the report is concerned, the OECD's model template entails three different tables. Table 1 constitutes the main part of the CbCR and contains information on all requested items. Specifically, MNEs would have to disclose the following figures on an aggregated basis (not per entity) for each tax jurisdiction they are operating in:

- Revenue (divided by unrelated and related party)

- Profit (loss) before income taxes

- Income tax paid (on cash basis)

- Income tax accrued - current year

- Stated capital

- Accumulated earnings

- Number of employees

- Tangible assets other than cash and cash equivalents

In general, data on profits and related tax payments in the relevant countries are intended to evaluate the appropriateness of the amounts of taxes paid. In addition, several further disclosures serve the purpose of examining a company's real economic activity in a country. Most importantly, the template includes income tax paid and income tax accrued in the respective jurisdictions. The first comprises profit taxes as well as withholding taxes of the group, whereas the latter includes taxes payable, but no deferred taxes or provisions for contingent tax liabilities. Overall, this tax reporting might include items not necessarily relating to the current period (such as tax prepayments, tax refunds or tax arrears).

16 Hardeck (2015) argue that the mandatory design of the proposal may be due to the fact that previous initiatives which were based on voluntary disclosures turned out not to be successful (see p. 397). 
Table 2 of the template is aimed at providing additional information on the group structure and on the business activities conducted in the involved jurisdictions, and thus on the value chain of the MNE. Table 3 offers the reporting MNE the opportunity to provide additional explanations.

In general, it is the ultimate parent entity's duty to file the transfer pricing and CbCR documents and to hand it in to its home jurisdiction's tax authority. Under certain circumstances, e.g. if the parent company's home country does not prescribe a CbCR or if there is no information exchange between the tax authorities, the obligation to file a CbCR can also be transferred to a domestic subsidiary. ${ }^{17}$ In case of non-compliance, the levy and collection of penalties is subject to national tax legislation.

Importantly, all of the CbCR information should only be reported confidentially to the tax authorities. This information would then be exchanged and made available to all relevant countries. While the EU directive and proposals on CbCR are conceptually very similar to the presented OECD approach, the most recent one differs significantly with regard to the kind of publication: Unlike the OECD, the EU suggests to additionally make certain parts of the CbC report publicly available. ${ }^{18}$ The information would be published in a stand-alone report accessible to the public for at least 5 years on the company's website.

Although the proposed guidelines can be considered as quite detailed, there is no explicit and distinct principle as regards the data source on which CbCR should be based. The only requirement stated is that the same data basis has to be used from year to year in order to preserve consistency. Nevertheless, there are various different sources that MNEs might refer to: For instance, consolidation reporting packages, separate entity financial statements or internal management accounts. In the following, we discuss which data source for providing tax disclosure may be most appropriate.

\subsection{Sources for providing (CbCR) information}

According to prevailing accounting standards (e.g. IFRS), consolidated financial statements disclose tax information in the profit and loss statement, the tax reconciliation and the segmental reporting. Building on consolidated accounts as a starting point for CbCR, however, has several drawbacks and does not seem to be feasible: Most importantly, consolidated financial statements are supposed to provide decision-useful information about a

17 For further information, see Lappé and Schmidtke (2015), p. 694.

18 Not all information items are included in the public CbCR e.g. revenues are reported in total only and information on tangible assets or share capital are not contained. 
group of companies as a single economic entity. Therefore, intra-group transactions are consolidated and do not affect the overall profit. Profit shifting activities by means of intragroup transactions are, thus, not visible in consolidated financial statements. This is due to the netting out of profits and expenses within the group. ${ }^{19}$ Tax reconciliations, on the other hand, only disclose the total tax reduction (i.e. a low ETR) due to operations in low tax jurisdictions, but do not specify the underlying profit shifting mechanisms or countries involved, as required by CbCR. Segmental reporting as another part of consolidated accounts does not deliver country-specific information either. According to the management approach (e.g. IFRS 8), data is disclosed on a business-unit level, yet not necessarily on a geographic or even per-country basis. Hence, in order to reveal single intra-group transactions, it would be necessary to examine "de-consolidated" data. This, however, does not serve the purposes of reporting on group level. In addition, financial statements contain data based on future prospects of the company, while CbCR is intended to detect profit shifting behavior in past periods. Therefore, it can be concluded that consolidated financial statements do not seem to be the appropriate source for CbCR information.

Alternatively, one could think of individual financial statements as a starting point for CbCR information. Although individual financial statements, as opposed to consolidated financial statements, contain unconsolidated data on single company level, such an approach would have several drawbacks as well. ${ }^{20}$ First, the exact source and direction of intra-group transactions do not become evident on a per-country basis. Second, individual financial statements are, in general, prepared according to local GAAPs and might be quite heterogeneous and thus not comparable across countries. Third and most importantly, financial accounts neither reflect taxable income nor do they provide reliable estimates for the true value of assets. As a general rule, book-tax-differences arise in most countries due to country-specific tax laws; the exemption from tax of certain types of income - in particular inter-company dividends and foreign source income - and non-deductible expenses are the most prominent examples. In addition, other reasons relating to different interrelations between financial accounting and national tax laws (e.g. different tax accounting standards and provisions to allocate income and expenses) are decisive for financial profits not necessarily to reflect taxable income. ${ }^{21}$ Regarding the reflection of the value of assets, in particular intangibles, it may be that they are not recorded at all, if self-developed, or only at

\footnotetext{
19 See van der Ham \& Tomson (2015), p. 844.

20 See, e.g., OECD (2013b).

21 See Endres et al. (2007); Schön (2005); Spengel and Zöllkau (2012).
} 
historical costs. Therefore, it would be misleading if, for example, a company had created intellectual property on its own and would display no or a very low value of intangible assets in its financial accounts on the one hand but would report high taxable profits from royalties on the other hand.

Other existing sources of information would come along with comparable drawbacks. Internal management data, for example, is expected to be even more heterogeneous among corporations as well as among countries due to a lack of standardization and binding reporting guidelines. The reporting practices would, therefore, be highly dependent on the internal processes of the MNEs and, thus, not be comparable at all.

To conclude, neither consolidated or individual financial statements nor other existing data sources can serve as a suitable basis for a comprehensive CbCR. Therefore, it would be necessary to define a standardized and harmonized set-up with respect to regulations and definitions (determination of income and valuation of assets). Such separate mandatory rules could, for example, be based on a harmonization of the determination of taxable income. In that regard, the European Commission has put forward a concept for a Common Consolidated Corporate Tax Base (CC(C)TB) in 2011 (European Commission (2011)). The proposed Council Directive provides a carefully prepared framework for a harmonized determination of corporate taxable income. The CCTB rules are, in principle, in line with tax accounting practice in the EU and are appropriate for harmonizing the tax base (Spengel and Zöllkau (2012)). Recently, the Action Plan for a Fair and Efficient Corporate Tax System published on June $17^{\text {th }} 2015$ by the European Commission focused once again on the concept of a CC(C)TB (European Commission (2015)). This could, therefore, be a promising avenue and data source for a comprehensive CbCR (at least within the EU). Finally, it has to be decided if and by whom the CbC report should be audited.

\subsection{Expected costs and benefits}

As a prerequisite for a CbCR to be meaningful at all, the expected benefits of any additional disclosure of tax information have to outweigh the expected costs. Yet, to date, little is known about the exact costs and benefits related to CbCR.

\subsubsection{Costs}

CbCR is suspected to be associated with several direct costs for disclosure. ${ }^{22}$ In addition, implicit costs occur; the volume of such implicit costs is likely to exceed that of direct costs

22 The following discussion of possible costs of a CbCR is adapted from Devereux (2011), pp. 34-38. 
for disclosure and depends on whether the disclosure is made public (as envisaged by the EU) or only available to tax authorities (as suggested by the OECD).

First of all, direct costs for disclosure would initially arise for adjusting existing systems and processes to the requirements of CbCR. While it is clear that these costs probably depend on various factors, such as the complexity of the group structure, there is no unanimity among experts as to whether the data collection for CbCR purposes generally is particularly burdensome or not. Some (Murphy (2009), p. 21) argue that many existing financial reporting systems are already technically able to deliver country-related data or that the necessary information even exists and can be derived from financial and internal accounts as well as from tax declarations (Kroppen (2013); Rödder and Pinkernell (2013); Heber (2013)). By contrast, others invoke substantial data-related costs contending that the established transfer pricing systems would need to be substantially expanded, as CbCR requires data that is not necessary for current transfer pricing analysis and is therefore not yet existing (e.g. Pinkernell (2014), p. 966). Moreover, since the proposals are not specific as regards the data base to be used, affected MNEs first of all need to spend resources on figuring out which data source works best for them. Direct costs for reporting would also be incurred for each CbC report on a regular basis. Not only would it be costly to collect all required information, but also to maintain data consistency across countries and across time. For instance, it is likely that multiple data sources are needed to gather all CbCR information and coordinating these different sources may be cumbersome (Lappé and Schmidtke (2015)). Moreover, conceptual and practical differences with regard to specific CbCR items may impose a challenge to consistency. As regards firms' declaration of profit taxes, it is, for example, common in the BRIC states to combine profit and sales taxes (Loitz (2015), M5). Data validity will, however, be limited if such inconsistencies emerge. Furthermore, direct costs relate to the potential necessity to audit the CbC report. Finally, CbCR could become expensive to the extent that companies consider it necessary to justify and extensively explain their reports to the public (Devereux (2011), p. 32ff.).

Next, implicit costs of CbCR would primarily stem from disclosing information to the public as envisaged by the EU proposal. Here, CbCR could be associated with considerable competitive disadvantages. Publishing commercially sensitive information is particularly problematic as country-specific reporting is not mandatory for all companies, but is restricted to large MNEs in specific countries. Hence, “small” MNEs outside the scope of CbCR may be able to use published data for non-tax reasons, e.g. for deriving business secrets (Hardeck 
(2015), p. 406). In addition, implementing public CbCR in the EU only would give rise to severe competitive disadvantages for MNEs operating within the EU compared to corporations conducting business exclusively outside the EU (Bärsch et al. (2016), p. 976). Thus, CbCR would constitute a considerable locational disadvantage for the EU. If it all, public CbCR should therefore only be implemented globally without any regional restrictions. More generally, disclosing data on tax payments potentially violates tax secrecy, which constitutes a guiding principle of tax law in most countries in the world. Even if CbC reports weren't disclosed to the public, but only to tax authorities, tax secrecy could be put at risk. As there are substantial international differences with regard to the scope of tax secrecy, ${ }^{23}$ it may turn out that the confidential treatment of CbCR data by foreign tax authorities cannot be ensured. To prevent harm to MNEs' competitiveness and to assure the confidentiality of CbCR data, countries would need to be required to enforce their legal standards with regard to tax secrecy (Cockfield and MacArthur (2015)).

In addition, international tax law is highly complex and public interested parties without profound knowledge of the subject or of the MNE's allocation of functions and risks might be unable to appropriately process and interpret the information disclosed. For instance, low (or zero) tax payments do not necessarily point to tax aggressiveness or at least do not necessarily result from illegal undertakings. Nevertheless, wrong accusations against companies could result (Reibel (2015), p. 210).

Another potential implicit cost of CbCR is associated with the danger of double taxation even in the absence of public disclosure: Knowing all tax payments on a country-by-country basis could make tax authorities, especially those of the increasingly powerful BRIC states, raise their own claims towards companies (Schlie and Malke (2013), p. 2469) and thus give rise to tax-related distributional conflicts (Pinkernell (2014), p. 971). Specifically, CbCR data could induce countries to arbitrarily make transfer pricing adjustments without any reference to the arm's length principle. Hence, CbCR could ultimately constitute an instrument to extend source taxation, especially by emerging and developing countries, and thus impose a threat in particular to firms with a strong export focus. In addition, the danger of double taxation not only pertains to the affected companies, but it may also come as a cost to tax authorities: For instance, according to Ditz and Quilitzsch (2014), the removal of double taxation vis-à-vis the BRIC countries often happens at the expense of German tax authorities. However, it also

${ }^{23}$ Only some countries, e.g. Finland, Sweden and Norway, require individual and/or corporate tax returns to be publicly disclosed. In Japan, public disclosure of individual and corporate tax return data was mandatory from 1950-2004 (see Hasegawa et al. (2013), p. 572). 
needs to be emphasized that the OECD explicitly states that it is the purpose of CbCR to enable the mere assessment of transfer pricing risk, rather than allowing for transfer pricing adjustments being made on the basis of CbCR data (OECD (2015a), p. 5). Yet, the overview on the global allocation of income, economic activity and tax payments may ultimately lead to calls for a global formulary apportionment system, which is expected to come at the expense of the tax bases of export oriented countries (Reibel (2015)), such as Germany.

\subsubsection{Benefits}

A major argument brought forward by proponents of CbCR is that companies would be urged to pay taxes at an amount that truly reflects the companies' economic activity and its utilization of public infrastructure in a particular country (Deutscher Bundestag (2013), p.1; Devereux (2011), p. 7). Indeed, CbCR could be a useful instrument to shed some light on MNEs' value chains and their actual economic circumstances (Fehling (2015)). Furthermore, the overview on the allocation of profits and tax payments may be beneficial for tax risk analysis and trigger audits where appropriate (Cockfield and MacArthur (2015)).

Yet, this reasoning is merely speculative, in particular since the common tax minimization strategies employed by multinationals are mostly based on the exploitation of loopholes in domestic and international tax laws and are therefore in itself not illegal. Moreover, the argument relating to the aim of assessing the appropriateness of profit allocation cannot be based on theoretical foundations, since it is virtually impossible to properly allocate profits and costs to single affiliates of a group by means of transfer prices: By setting up an integrated group of companies, coordination of transactions via markets is abandoned in favor of coordination using intra-organizational hierarchies. The aim is to generate economies of integration, for example by means of lower transaction costs, improvement of information flows or managerial efficiency. As a result, the profits of an integrated group of companies are higher than the aggregate profits earned by its separate entities. Since the excess profits accrue at group level, it is theoretically impossible to determine the source of these profits as they cannot be attributed to specific and, above all, individual transactions either (Mclure (1984), p. 94ff.; Avi-Yonah and Benshalom (2011), p. 379; Jacobs et al. (2016), p. 636f.; Schön (2010), p. 233ff.; Ault (2013), p.1200f.; Oestreicher (2016)). Moreover, MNEs' profits nowadays are substantially driven by intangible assets that are hardly locatable and very difficult to value (Oestreicher (2014)).

Even if one accepts transfer pricing as an appropriate means for profit allocation, various experts doubt the OECD’s claim that CbCR information is useful to examine transfer pricing 
or even BEPS-related risks and to assess whether an appropriate amount of taxes has been paid (Kroppen and Rasch (2014)). More generally, one could even contend that it is not reasonably possible to relate taxes paid and annual profits of a single fiscal year, given that the reported items may be impacted by transactions relating to other periods (e.g. loss carryforwards); i.e. high profits and low tax payments do not necessarily need to be at odds.

In addition, it is also questionable to what extent CbCR actually entails additional insights and benefits for tax authorities. Tax authorities can be assumed to be already familiar with the common (legal) tax planning channels and arrangements used for profit shifting, ever since the most prominent examples have been made available to the public (Pinkernell (2012), p. 369ff.; Kleinbard (2011), p. 707ff.). Furthermore, it is not even clear whether tax authorities have sufficient resources to process and utilize CbCR data. It seems to be - above all - of high interest of large NGOs.

CbCR, therefore, might only provide hints as regards the question of which companies should be audited or examined with increased scrutiny. This might be relevant for inbound investments in particular. Then, however, it could be argued that it is not necessary to stick to the EU's proposal and make CbCR publicly accessible, i.e. it would be sufficient to make the information available to fiscal authorities only.

If, however, CbCR information were made available to the public, proponents of CbCR also claim that an enlarged information set would be beneficial from a capital market point of view. For instance, knowing which countries a multinational operates in could potentially enable investors to better assess the companies' geo-political risk and the sustainability of its tax charge (Murphy (2009), p. 14). ${ }^{24}$ Yet, some empirical evidence suggests that capital market participants already face an information overload and do not actually consider the full information set available (Lenter et al. (2003), p. 823ff.; Raedy et al. (2011), p. 3).

There is, however, some empirical evidence indicating a negative relationship between enhanced disclosures (transparency) and tax aggressiveness. For instance, Dyreng et al. (2016) find that firms which are subject to public scrutiny engage less in tax avoidance, indicating that public pressure can exert some influence on MNEs. In a similar vein, Herbert et al. (2015) contend that reduced public disclosure is positively correlated with international tax avoidance. Hence, this finding may speak in favor of increased disclosures as required by CbCR. There even is some evidence for negative reputational effects of tax sheltering: Hanlon

24 Investors could for instance see whether the tax charge largely depends on operations located in tax haven countries. 
and Slemrod (2009) find, on average, negative stock price reactions when there is news about a firm's involvement in tax shelters.

Yet, the question remains as to whether CbCR is actually suitable to uncover such tax shelters and to substantially reduce tax minimization grounded on the utilization of beneficial regimes and constructional flaws in international tax law. Overall, public pressure resulting from CbCR would be rather expected in case of illegal endeavors, which, however, are mostly not the reason for the strikingly low effective tax rates of multinationals currently observed. Thus, it also remains uncertain whether CbCR would actually exert any persistent influence on customers’ purchase decisions.

\subsubsection{Interim conclusion}

To sum up, it can be concluded that the expected benefits of CbCR (at least partially) lack a theoretical foundation and, overall, do not seem to outweigh the associated costs. Given the particularly high costs associated with public disclosure, CbCR should only be made available to tax authorities - as it is proposed by the OECD -, if at all. To keep implementation costs as low as possible, there is a need to clearly specify which distinct data source has to be used by reporting MNEs. It also has to be made sure that tax secrecy is reinforced in all participating countries and that CbCR is not exploited by tax authorities as a means to extend source taxation.

Overall, it appears to be more reasonable to combat tax aggressiveness by different means. It is, therefore, up to legislators to remove unintended gaps and loopholes in tax laws.

\section{Alternatives}

As discussed above, it seems unlikely that legal tax planning activities can be combated by means of a CbCR. Rather, it might be more effective to limit the leeway companies have with respect to constructing tax minimizing group structures. Empirical evidence reveals intragroup financing and transfer pricing as the most prominent channels for multinationals' profit shifting. In a recent meta-analysis, Heckemeyer and Overesch (2013) show that transfer pricing is by far the most dominant profit shifting channel. While transfer pricing explains $72 \%$ of the total share of shifted profits, the share of intra-group financing amounts to $28 \%$ only (Heckemeyer and Overesch (2013), pp. 23ff.). Further empirical evidence shows that enforcing tax rules does indeed reduce tax aggressive behavior of multinational companies.

One example for the tightening of tax rules has been the enforcement of transfer pricing rules in the last years. Lohse et al. (2012) aim to generate a measure for the stringency and impact 
of transfer pricing rules showing that the regulations have become stricter over time. Lohse and Riedel (2013) use these insights to demonstrate that such transfer pricing regulations significantly reduce profit shifting activities by up to 50\% (measured by the sensitivity of corporate pre-tax profits to changes in the corporate income tax rate). In particular, penalties exert an additional limiting effect on profit shifting behavior. Furthermore, they argue that higher administrative costs arising from additional documentation requirements can be justified in the light of anticipated benefits. In line with that, Beer and Loeprick (2015) find that, on average, estimated profit shifting among MNE subsidiaries is reduced by 52\% two years after the introduction of mandatory documentation requirements. In addition, Luckhaupt et al. (2012) point out the importance of a standardized set of transfer pricing rules in order to decrease complexity and to actually reduce the leeway for profit shifting. ${ }^{25}$

With regard to intra-group financing, various studies have also revealed the effectiveness of thin capitalization rules. Buettner et al. (2012) find that thin-capitalization rules effectively reduce multinationals’ incentive to make use of internal loans for international tax planning. Blouin et al. (2014) obtain similar results concerning the effectiveness of thin capitalization rules with respect to their impact on the capital structure of multinational firms (reduction of internal debt).

A promising avenue might therefore be to close gaps and loopholes and to reduce leeway in domestic and international tax laws. However, in that case, it would be important to ensure that tightened regulations do not lead to double taxation, i.e. these regulations would have to be universally accepted by all countries.

\section{Conclusion}

(1) Aggressive tax planning efforts of highly profitable multinational companies (so called Base Erosion and Profit Shifting (BEPS)) have become the subject of intense public debate in recent years. As a response, several international initiatives and parties have called for more transparency in tax reporting, especially by means of a Country-byCountry Reporting (CbCR).

(2) Certain regulations requiring country-specific information have already been put in place for the extractive and financial sectors. Recently, the OECD and the European Commission have additionally presented proposals for a comprehensive disclosure of country-specific tax-related information for companies in all industry sectors.

\footnotetext{
25 In particular, they propose an apportionment method for those profits that cannot be allocated by transfer pricing.
} 
(3) These proposals envisage CbCR to constitute a separate part of MNEs' transfer pricing documentation. Taxpayers would be obliged to report income, taxes paid and certain indicators of economic activity for each jurisdiction they operate in separately. While the OECD suggests a confidential disclosure of CbCR information to tax authorities, the EU additionally wants to make CbCR - or at least parts of it - publicly available.

(4) Our findings suggest that neither consolidated or individual financial statements nor other existing data sources seem to be an appropriate basis for providing such country-specific information. Instead, it would be necessary to define detailed and harmonized definitions and regulations to ensure comparability. The concept of a Common Consolidated Corporate Tax Base (CC(C)TB) could be a promising avenue in that regard.

(5) The discussion on benefits and costs of a CbCR reveals that benefits (at least partially) lack a theoretical foundation and, overall, do not seem to outweigh associated costs. This holds true, in particular, since current tax planning activities are mainly based on the legal exploitation of gaps and loopholes in national and international tax law. Overall, it appears to be more reasonable to combat tax aggressiveness by means other than CbCR.

(6) Alternatively, tax legislators should remove gaps and loopholes in tax laws. Specifically, the enforcement of national and international tax rules should be considered. This is in accordance with recent empirical evidence demonstrating the effectiveness of thin-cap rules and tightened transfer pricing regulations. 


\section{References}

Ault, H.J. (2013), Some Reflections on the OECD and The Sources of International Tax Principles, Tax Notes International, pp. 1195-1201.

Avi-Yonah, R. / Benshalom, I. (2011), Formulary apportionment - myths and prospects: promoting better international tax policies by utilizing the misunderstood and undertheorized formulary alternative, World Tax Journal, pp. 371-398.

Bach, S. (2013), Unternehmensbesteuerung: Hohe Gewinne - mäßige Steuereinnahmen, DIW Wochenbericht, pp. 3-12.

Bärsch, S.E. / Engelen C. / Färber, N. (2016), Die Dokumentation von Verrechnungspreisen und das Country-by-Country Reporting - Die neuen Anforderungen der OECD und der EU -, Der Betrieb, pp. 972-982.

Beer, S. / Loeprick, J. (2015), Profit shifting: driver of transfer (mis)pricing and the potential of countermeasures, International Tax and Public Finance, pp. 426-451.

Blouin, J. / Huizinga, H. / Laeven, L. / Nicodème, G. (2014), Thin Capitalization Rules and Multinational Firm Capital Structure, Working Paper.

Buettner, T. / Overesch, M. / Schreiber, U. / Wamser, G. (2012), The impact of thincapitalization rules on multinationals' financing and investment decisions”, Journal of Public Economics, pp. 930-938.

Cockfield, A.J. / MacArthur, C.D. (2015), Country-by-Country Reporting and Commercial Confidentiality, Canadian Tax Journal, pp. 627-660.

Clausing, K.A. (2003), Tax-motivated transfer pricing and US intrafirm trade prices, Journal of Public Economics, pp. 2207-2223.

Congress of the United States of America (2010), Dodd-Frank Wall Street Reform and Consumer Protection Act, Washington.

Desai, M.A. / Foley, C.F. / Hines, J.R. (2004), A Multinational Perspective on Capital Structure Choice and Internal Capital Markets, The Journal of Finance, pp. 24512487.

Desai, M.A. / Foley, C.F. / Hines, J.R. (2006), The demand for tax haven operations, Journal of Public Economics, pp. 513-531. 
Deutscher Bundestag (2013): Antrag der Fraktionen SPD und BÜNDNIS 90/DIE GRÜNEN - Steuerzahlungen multinationaler Unternehmen transparent machen - Country-byCountry Reporting in Deutschland einführen und in Europa vorantreiben, Berlin.

Devereux, M. (2011), Transparency in reporting financial data by multinational corporations, Project Report, Oxford University Centre for Business Taxation.

Dharmapala, D. / Riedel, N. (2013), Earnings shocks and tax-motivated income-shifting: Evidence from European multinationals, Journal of Public Economics, pp. 95-107.

Dharmapala, D. (2014), What do we know about Base Erosion and Profit Shifting? A Review of the Empirical Literature, Fiscal Studies, pp. 421-448.

Dischinger, M. / Riedel, N. (2011), Corporate taxes and the location of intangible assets within multinational firms, Journal of Public Economics, pp. 691-707.

Ditz, X. / Quilitzsch, C. (2014), Erweiterung von Offenlegungspflichten durch Country by Country Reporting: Steuerpolitischer Nutzen und verfahrensrechtliche Grenzen, DStR, pp. 127-131.

Dyreng, S.D. / Hoopes, J.L. / Wilde, J.H. (2016), Public Pressure and Corporate Tax Behavior, Journal of Accounting Research, pp. 147-186.

Egger, P. / Eggert, W. / Winner, H. (2010), Saving taxes through foreign plant ownership, Journal of International Economics, pp. 99-108.

http://eiti.org, accessed 15 December 2013.

http://en.g20russia.ru/news/20131129/784497471.html, accessed 19 December 2013.

Endres, D. / Oestreicher, A. / Scheffler, W. / Spengel, C. (2007), The Determination of Corporate Taxable Income in the EU Member States, Alphen an den Rijn.

European Commission (2011), Proposal for a Council Directive on a Common Consolidated Corporate Tax Base (CCCTB), KOM(2011) 121/4.

European Commission (2013), G20 summit: Improving global confidence and support the global recovery - Joint letter of the Presidents of the European Commission and the European Council, Memo/13/717.

European Commission (2015), Communication from the Commission to the European Parliament and the Council - A Fair and Efficient Corporate Tax System in the European Union: 5 Key Areas for Action, COM (2015) 302 final, Brussels. 
European Commission (2016a), Communication from the Commission to the European Parliament and the Council - Anti Tax Avoidance Package: Next Steps towards delivering effective taxation and greater tax transparency in the EU.

European Commission (2016b), Proposal for a COUNCIL DIRECTIVE amending Directive 2011/16/EU as regards mandatory automatic exchange of information in the field of taxation.

European Commission (2016c), Council Directive (EU) 2016/881 of 25 May 2016 amending Directive 2011/16EU as regards mandatory automatic exchange of information in the field of taxation.

European Commission (2016d), Proposal for a DIRECTIVE OF THE EUROPEAN PARLIAMENT AND OF THE COUNCIL amending Directive 2013/34/EU as regards disclosure of income tax information by certain undertakings and branches.

Evers, M.T. / Meier, I. / Spengel, C. (2014), Transparency in Financial Reporting: Is Country-by-Country Reporting suitable to combat international profit shifting?, Bulletin for International Taxation, pp. 295-303.

Fehling, D. (2015), Das BEPS-Projekt auf der Zielgeraden - was bedeutet dies für Deutschland?, Finanz-Rundschau Ertragsteuerrecht, pp. 817-823.

Fuest, C. / Hebous, S. / Riedel, N. (2011), International debt shifting and multinational firms in developing economies, Economics Letters, pp. 135-138.

Fuest, C. / Spengel, C. / Finke, K. / Heckemeyer, J.H. / Nusser, H. (2013), Profit Shifting and „Aggressive“ Tax Planning by Multinational Firms: Issues and Options for Reform, World Tax Journal, pp. 307-324.

Grubert, H. / Mutti, J. (1991), Taxes, Tariffs and Transfer Pricing in Multinational Corporate Decision Making, The Review of Economics and Statistics, pp. 285-293.

Hanlon, M. / Slemrod, J. (2009), What does tax aggressiveness signal? Evidence from stock price reactions to news about tax shelter involvement, Journal of Public Economics, pp. 126-141.

van der Ham, S. / Tomson, S. (2015), Datenerfassung für den Country-by-Country Report, Internationale Wirtschaftsbriefe, pp. 841-849. 
Hardeck, I. (2015), Legen Unternehmen freiwillig Steuerinformationen offen? Eine deskriptive Analyse am Beispiel des Country-by-Country Reportings in der Rohstoffindustrie, Betriebswirtschaftliche Forschung und Praxis, pp. 397-418.

Herbert, T. / Olligs, P. / Overesch, M. (2015), Public Disclosure of Foreign Subsidiaries and Aggressive International Tax Avoidance, Working Paper.

Hasegawa, M. / Hoopes, J.L. / Ishida, R. / Slemrod, J. (2013), The Effect of public disclosure on reported taxable income: Evidence from individuals and corporations in Japan, National Tax Journal, pp. 571-608.

Heber, C. (2013), Rechnungslegung nach Ländern als Möglichkeit zur Verbesserung der Informationsbeschaffung der Abgabenbehörden, Internationales Steuerrecht, pp. 522527.

Heckemeyer, J.H. / Overesch, M. (2013), Multinationals' Profit Response to Tax Differentials: Effect Size and Shifting Channels, ZEW-Discussion Paper No. 13-045.

Heckemeyer, J.H. / Spengel, C. (2008), Ausmaß der Gewinnverlagerung multinationaler Unternehmen - empirische Evidenz und Implikationen für die deutsche Steuerpolitik, Perspektiven der Wirtschaftspolitik, pp. 37-61.

Hines, J.R. / Rice, E.M. (1994), Fiscal Paradise: Foreign Tax Havens and American Business, The Quarterly Journal of Economics, pp. 149-182.

Huizinga, H.P. / Laeven, L. (2008), International profit shifting within multinationals: A multi-country perspective, Journal of Public Economics, pp. 1164-1182.

Jacobs, O.H. / Endres, D. / Spengel, C. (2016), Internationale Unternehmensbesteuerung, 8th Edition, Munich.

Karkinsky, T. / Riedel, N. (2012), Corporate taxation and the choice of patent location within multinational firms, Journal of International Economics, pp. 176-185.

Kleinbard, E. (2011), Stateless Income, Florida Tax Review, pp. 699-773.

Kroppen, H.K. (2013), International Aspekte einer Reform der Unternehmensbesteuerung, 38. Jahrestagung Deutsche Steuerjuristische Gesellschaft e.V., Berlin, 9./10.9. 2013.

Kroppen, H.K. / Rasch, S. (2014), Country-by-Country Reporting: Die neue Sichtweise der OECD zur Verrechnungspreisdokumentation, IStR, pp. 358-363. 
Lappé, S. / Schmidtke, R. (2015), Praxisrelevante Fragestellungen im Zusammenhang mit der Einführung des Country-by-Country Reportings, IStR, pp. 693-698.

Lenter, D. / Slemrod, J. / Shackelford, D. (2003), Public Disclosure of Corporate Tax Return Information: Accounting, Economics, and Legal Perspectives, National Tax Journal, pp. 803-830.

Lohse, T. / Riedel, N. / Spengel, C. (2012), The increasing importance of transfer pricing regulations - a worldwide overview, Oxford Center for Business Taxation Working Paper WP 12/27.

Lohse, T. / Riedel, N. (2013), Do Transfer Pricing Laws limit International Income Shifting? Evidence from European Multinationals, Oxford University Centre for Business Taxation Working Paper 13/07.

Loitz, R. (2015), Country by Country Reporting aus Sicht des Accounting, Der Betrieb, pp. M5.

Luckhaupt, H. / Overesch, M. / Schreiber, U. (2012), The OECD Approach to Transfer Pricing: A Critical Assessment and Proposal, in: W. Schön and K. Konrad (Eds.) (2012), Fundamentals of International Transfer Pricing in Law and Economics, Berlin/Heidelberg, pp. 91-121.

Mclure, C.E. (1984), Defining a Unitary Business: An Economist's View, in: C.E. Mclure (Ed.) (1984), The State Corporation Income Tax: Issues in Worldwide Unitary Combination, Stanford, pp. 89-124.

Murphy, R. (2009), Country-by-Country Reporting - Holding multinational corporations to account wherever they are, Task Force on Financial Integrity and Economic Development.

Murphy, R. (2012), Closing the European Tax Gap - A Report for Group of the Progressive Alliance of Socialists \& Democrats in the European Parliament, Tax Research LLP.

OECD (2013a), Action plan on Base Erosion and Profit Shifting, OECD Publishing.

OECD (2013b), Memorandum on Transfer Pricing Documentation and Country by Country Reporting, OECD Publishing.

OECD (2014a), Discussion Draft on Transfer Pricing Documentation and CbC Reporting, OECD Publishing. 
OECD (2014b), Guidance on Transfer Pricing Documentation and CbC Reporting, OECD Publishing.

OECD (2015a), Action 13: Guidance on the Implementation of Transfer Pricing Documentation and Country-by-Country Reporting, OECD Publishing.

OECD (2015b), Action 13: Country-by-Country Implementation Package, OECD Publishing.

OECD (2015c), Transfer Pricing Documentation and Country-by-Country Reporting, Action 13: 2015 Final Report, OECD Publishing.

OECD (2015d), Measuring and Monitoring BEPS, Action 11: 2015 Final Report, OECD Publishing.

Oestreicher, A. (2014), Verhinderung von "Base Erosion and Profit Shifting" durch Verrechnungspreisdokumentation, Der Betrieb, Beilage 5 zu Heft Nr. 47, pp. 1-9.

Oestreicher, A. (2016), To see or not to see, das ist keine Frage, Der Betrieb, Heft Nr. 20, M5.

Oxfam (2000), Tax Havens: Releasing the Hidden Billions for Poverty Eradication, Oxfam International Policy Paper.

Pinkernell, R. (2012), Ein Musterfall zur internationalen Steuerminimierung durch USKonzerne, Steuer und Wirtschaft, pp. 369-374.

Pinkernell, R. (2014), Neue OECD-Grundsätze zur Verrechnungspreisdokumentation und Country-by-Country Reporting (Maßnahme 13 des BEPS-Aktionsplans), FinanzRundschau Ertragsteuerrecht, pp. 964-971.

Raedy, J.S. / Seidman, J. / Shackelford, D. (2011), Is There Information in the Tax Footnote?, McCombs Research Paper Series No. ACC-01-11, Working Paper.

Reibel, R. (2015), Tax Transparency - How To Make It Work?, European Taxation, pp. 209212.

Rödder, T. / Pinkernell, R. (2013), Zum Seminar F: 20 Thesen zur BEPS Diskussion, Internationales Steuerrecht, pp. 619-623.

Schlie, I. / Malke, C. (2013), Country by Country Reporting im Hinblick auf Steuerzahlungen multinationaler Unternehmen - Aktuelle Entwicklungen und Diskussionsbedarf, Der Betrieb, pp. 2467-2470.

Schön, W. (2005), Steuerliche Maßgeblichkeit in Deutschland und Europa, Köln. 
Schön, W. (2010), International Tax Coordination for a Second-Best World (Part III), World Tax Journal, pp. 227-261.

Spengel, C. / Zöllkau, Y. (2012), Common Corporate Tax Base (CC(C)TB) and Determination of Taxable Income - An International Comparison, Berlin/Heidelberg. 